\title{
Analisa Perbandingan Statistik Kelemahan SPI dan Biaya Politik sebagai Pemoderasi Kerugian Keuangan Daerah pada Belanja Daerah
}

\author{
Ajie Amiseno ${ }^{(1)}$, Nunuy Nur Afiah ${ }^{(2)}$, Devianti Yunita ${ }^{(3)}$ \\ ${ }^{1,2,3}$ Program Studi Magister Akuntansi Universitas Padjadjaran Bandung \\ Jalan Japati No. 4. Telp (022) 2535172 Bandung 40133 \\ e-mail: ajie.amiseno@bpk.go.id
}

\begin{abstract}
ABSTRAK
Permasalahan korupsi sudah lama menjadi masalah di Indonesia. Pemerintah telah berbagai upaya untuk memerangi korupsi yang merugikan keuangan negara/daerah. Korupsi sendiri erat berkaitan dengan kecurangan. Belanja Modal dinilai sering menjadi target korupsi sehingga terjadi kerugian keuangan daerah. Kelemahan SPI dan Biaya Politik diduga menjadi faktor penyebabnya. Studi ini dilakukan di lingkungan Pemerintah Daerah di Indonesia. Riset ini bertujuan untuk mengatahui apakah Kelemahan SPI dan Biaya Politik benar-benar memperkuat terjadinya korupsi yang menyebabkan Kerugian Keuangan Daerah. Analisa yang digunakan adalah membandingkan kekuatan statistik (R-Square) antara persamaan regresi yang dibentuk dengan masing-masing variabel moderasi (Kelemahan SPI dan Biaya Politik). Hasil penelitian menunjukkan bahwa Kelemahan SPI dan Biaya Politik sama-sama memperkuat hubungan moderasi antara Belanja Modal dengan Kerugian Keuangan Daerah. Namun demikian, Kelemahan SPI lebih kuat memoderasi hubungan tersebut daripada Biaya Politik.

Kata kunci : Kerugian Keuangan Daerah, Belanja Modal, Kelemahan SPI, Biaya Politik, Korupsi, Fraud

\section{ABSTRACT}

Indonesia a has long history of combating corruption. The Government of Indonesia is still struggling to deal with corruption or fraud that causes state financial loss in central. Provincial, and local government level. Corruption has strong affiliation with fraud. Most of corruption cases occur on Government Capital Spending. Internal Control Weaknesses and Electoral Cost suspect as a root cause of corruption. This study performed in Provincial and Local Government Level. This research aims to determine the moderating effect of Internal Control Weaknesses and Electoral Cost on Capital Spending - State Financial Loss correlation. The result of this research indicates both Internal Control Weaknesses and Electoral Cost strengthen Capital Spending - State Financial Loss correlation. However, Internal Control Weaknesses have a more strong moderating effect than Electoral Cost.

Keywords : State Financial Loss, Capital Spending, Internal Control Weaknesses, Electoral Cost, Corruption, Fraud.
\end{abstract}

\section{PENDAHULUAN}

Sejak lama Indonesia menghadapi permasalahan korupsi. Pemerintah telah berupaya mengeluarkan berbagai peraturan perundangan untuk mengatasi permasalahan korupsi. Bahkan Pemerintah mewajibkan setiap instansi pemerintah untuk menyelenggarakan Sistem Pengendalian Intern (SPI). SPI sendiri diyakini dapat mencegah kehilangan sumber daya suatu organisasi sebagai akibat tindak kecurangan (Shao, 2016). Namun demikian, masih ditemukan permasalahanpermasalahan penyelenggaraan SPI di lingkungan Instansi Pemerintah. Permasalahan-permasalahan tersebut dikenal sebagai permasalahan Kelemahan SPI.

Semenjak diundangkannya Undang-Undang Pemberantasan Tindak Pidana Korupsi, Indonesia masih menghadapi berbagai kasus-kasus korupsi misalnya kasus Pengadaan KTP Elektronik, Kasus
Wisma Atlet, Kasus SHS, dan Flu Burung (Kompas, 2018). Kasus-kasus korupsi tersebut sering terjadi pada Belanja Modal. Menurut Jusuf Kalla, Belanja Modal sering menjadi sasaran korupsi (Republika, 2017). Wakil Ketua KPK juga berpendapat bahwa kasus korupsi lebih banyak berupa penggelapan pada proses pengadaan rata-rata dengan pemotongan rata-rata mencapai hampir sebesar $10 \%$ dari nilai proyek.

Selain itu, kasus korupsi juga terjadi di tingkat Pemerintah Daerah. Sejak tahun 2012 sampai dengan 2016 nilai kasus temuan korupsi yang menyebabkan kerugian keuangan daerah yang ditemukan BPK RI mencapai Rp10.160.649.753.333 (IHPS, 2017). Wakil Ketua KPK menyebutkan bahwa kasus korupsi yang banyak terjadi disebabkan karena tingginya biaya politik. 
Fenomena-fenomena tersebut menimbulkan pertanyaan penelitian apakah

a. Kelemahan SPI pada Belanja Modal dapat menyebabkan Kerugian Keuangan Daerah?

b. Biaya Politik pada Belanja Modal dapat menyebabkan Kerugian Keuangan Daerah?

c. Apakah Kelemahan SPI atau Biaya Politik yang lebih menyebabkan Kerugian Keuangan Daerah pada realisasi Belanja Modal?

\section{Kajian Pustaka}

\section{Kerugian Keuangan Daerah}

Keuangan Daerah merupakan semua hak dan kewajiban daerah yang dapat dinilai dengan uang dan segala sesuatu berupa uang dan barang yang dapat dijadikan milik daerah yang berhubungan dengan pelaksanaan hak dan kewajiban tersebut (Vide: Pasal 1 UU No. 17 Tahun 2013 tentang Keuangan Negara). Kerugian Keuangan Daerah erat kaitannya dengan tindak kecurangan (fraud). Kecurangan didefinisikan sebagai tindakan tidak benar yang menyebabkan kerugian bagi korban kecurangan dan menguntungkan pelaku kecurangan (Millichamp dan Taylor, 2012 : 305). Salah satunya adalah penyalahgunaan aset seperti penggelapan aset (terutama kas), belanja fiktif, dan pemanfaatan aset untuk tujuan pribadi (Millichamp dan Taylor 2012:306, Elder et all,2011 : 400, Arrens et all, 2012:356).

Penyebab tindakan kecurangan ditinjau dari perspektif ilmu sosial psikologi antara lain adalah penjelasan Rational Choice Theory (RCT) dimana setiap orang bertindak atas kepentingan pribadi (Dowding, et all, 1995 : 1). Selain itu, menurut Differential Association Theory (DAT) berpendapat bahwa interaksi antar individu membentuk nilai pada pribadi manusia (Cressey, 1954). Dengan memperhatikan teori sosial psikologi lain seperti Social Exchange Theory (RET) yang berpendapat bahwa interaksi antar umat manusia berdasarkan pertukaran manfaat dan risiko (Cook dan Rice, 2003 :53), Social Comparison Theory (SCT) yang berpendapat bahwa manusia selalu melakukan evaluasi diri berdasarkan opini dan perbandingan diri manusia itu sendiri, serta Terror Management Theory (TMT) yang menyatakan bahwa manusia cenderung percaya untuk menjaga self-esteem-nya (Greenberg, 1990) maka dapat disimpulkan bahwa manusia yang tumbuh dalam lingkungan yang penuh dengan tindak kecuarangan maka kemungkinan manusia tersebut secara psikologi cenderung berperilaku curang. Dari perspektf lain, alasan seseorang untuk bertindak curang adalah adanya kesempatan, rasionalisasi, insentif (Cressey,
1953), dan adanya kemampuan untuk bertindak kecurangan (Hermanson, $2004: 38$ ).

Dalam organisasi pemerintah kecurangan dapat terjadi dalam pengeluaran anggaran dan dikategorikan sebagai korupsi (Kurniawan 2015:7). Definisi korupsi sendiri tidak lepas dari adanya unsur kerugian keuangan negara/daerah (Yuntho et all, 2013, Saputra, 2015, Surachmin dan Cahya, 2011:17) sedangkan perhitungan Kerugian Keuangan Negara/Daerah merupakan wewenang BPK sehingga pengukuran kerugian keuangan daerah (Y - Variabel Dependen) pada penelitian ini dikur dari presentase temuan kerugian negara terhadap belanja modal daerah (Yusuf dan Aryani, 2015, dan Widyatuti, 2016).

\section{Kelemahan Sistem Pengendalian Intern}

Sistem Pengendalian Intern (SPI) merupakan rangkaian atau kombinasi dari kebijakan atau prosedur yang dibangun agar manajemen memperoleh keyakinan yang memadai untuk mencapai tujuan dan sasaran organisasi (Rai, 2008:293). Ditinjau dari perspektif teori keorganisasian System Theory (Bertalanffy, 1968) yang diperluas dalam Open System Theory (Clawson, 2008), SPI yang lahir melalui Sarbanes Oxlay Act diangap penting setelah terjadinya Kasus Parmalat dan Skandal Enron (Heider, 1958). Hal tersebut merupakan jawaban atas berkembanganya kasus kecurangan, keilmuan terkait kecurangan, dan bagaimana memperkecil peluang kecurangan dengan SPI (Mackevicius dan Lukas, 2012).

Indonesia mulai mewajibkan penyelenggaraan SPI melalui PP 60 Tahun 2008 tentang SPIP. Unsur dari SPI adalah Lingkungan Pengendalian, Penilaian Risiko, Kegiatan Pengendalian, Informasi dan Komunikasi, dan Pemantauan. Namun tidak seluruh Instansi Pemerintah dapat menyelenggarakan unsur SPI secara efektif. BPK Sendiri melakukan penilaian atas kelemahan penyelenggaraan SPI. Bukti empiris menunjukkan bahwa unsur SPI yang paling penting dalam pengendalian intern adalah Kegiatan Pengendalian (Boyle dan Cooper, 2004). Hal ini ditunjukkan dengan penelitian Yasmin dan Sutaryo (2017) yang menyatakan bahwa $61 \%$ temuan kelemahan SPI adalah kelemahan pada Kegiatan Pengendalian. Sehingga pengukuran Variabel Kelemahan SPI (X1) diukur dari temuan kelemahan kegiatan pengendalian yang berhasil diidentifikasi BPK.

\section{Belanja Modal Pemerintah}

Dalam akuntansi dana proses akuisisi aset yang pemanfaataanya lebih dari satu tahun maka organisasi publik membentuk capital project fund untuk mempermudah dan mengatur pertanggung- 
jawaban belanja pemerintah (Ruppel, 2014 : 2014 : 76). Dengan diterapkannya International Public Sector Accounting Standards maka pemerintah mempertangungjawabkan pengeluaran pemerintah untuk akusisi aset dengan pendekatan akuntansi akrual. Hal tersebut didefinisikan sebagai Belanja Modal yaitu pengeluaran anggaran untuk memperoleh tanah, bangunan, gedung, aset tak berwujud, dan peralatan (PP 71/2010). Karena besaran belanja modal berbeda-beda disetiap daerah maka pengukuran variabel Belanja Modal (X2) diukur dengan angka persentase realisasi belanja modal terhadap belanja daerah (Fitri, 2014, Saerang dan Elim, 2016, Martini dan Dwiandra, 2015).

\section{Biaya Politik}

Kelemahan dari sistem demokrasi adalah adanya "Mob Rule" dan "Oppresion of Majority" dimana sistem demokrasi cenderung memenangkan suara terbanyak atau menguasai massa (Robert, 2016). Hal tersebut menimbulkan adanya risiko apabila masyarakat banyak yang berpikir materialistis terutama masyarakat miskin (Holish, Rohmat, Syarifudin, 2018). Sesuai dengan DAT dan RCT maka dapat dimungkinkan terjadinya pembelian kekuasaan oleh pihak yang secara psikologis mempertahankan esteem TMT dan SCT.

Biaya politik adalah biaya yang harus dikeluarkan untuk memenangkan pemilu (Fitriyah, 2013). Menurut Fitriyah (2013), Untuk menjadi calon kepala daerah diperlukan biaya "sewa perahu" yaitu biaya yang dibayar sebelum atau sesudah penetapan calon kepala daerah. Fitriyah (2013) juga memperkirakan terdapat pengusaha yang memiliki kepentingan ekonomi tertentu pada calon kepela daerah bahkan menentukan siapa yang akan terpilih sebagai kepala daerah. Hal tersebut menunjukkan beberapa calon kepala daerah berpotensi terlibat politik uang. Politik uang didefinisikan sebagai upaya mempengaruhi perilaku orang lain dengan menggunakan imbalan tertentu (Irawan, 2015) Politik uang terjadi tidak hanya pada saat penetapan calon melainkan sampai dengan termasuk pembelian suara ke pemilih (Fitriyah, 2013, Milyo, 2015).

Biaya Politik tinggi salah satunya merupakan akibat dari politik uang. Strategi politik uang antara lain adalah serangan fajar dan mobilisasi massa (Irawan, 2015). Serangan fajar merupakan praktik untuk membeli suara dengan uang sedangkan mobilisasi massa merupakan pertukaran ekonomi atas suara dari massa yang akan memilih (Irawan, 2015). Menurut Abhan (2018:1) selaku Ketua Banwaslu mengungkapkan Banwaslu telah menyusun Indeks Kerawanan Pemilu (IKP) yang salah satunya menilai aspek adanya politik uang dalam mendeteksi kerawanan pemilu (IKP-Money
Politics). Untuk itu daerah-daerah yang memiliki IKP tinggi perlu mendapatkan perhatian karena rawan terjadi penyimpangan politik yang tinggi (Sendhikasari dan Hantoro, 2016). Dengan demikian semakin tinggi IKP suatu daerah maka semakin tinggi biaya politiknya. IKP-Money Politics sejalan dengan penelitian Robert (2016) yang menyatakan adanya "Mob Rule" dengan memperhatikan DAT dan RCT serta penelitian Holish, Rahmat, dan Syariffudin (2018) yang menyatakan adanya risiko apabila mayoritas daerah pemilihan adalah masyarakat miskin maka pengukuran variabel Biaya Politik (X3) diukur dengan IKP-Money Politics.

\section{METODE PENELITIAN}

Penelitian ini menggunakan desaian kausalitas dengan menggunakan data sekunder. Penelitian ini merupakan penelitian lapangan dengan unit analisis pemerintah daerah di Indonesia. Penelitian ini menghitung kecukupan sampel sebesar 85 sampel dari 548 populasi Pemerintah Daerah di Indonesia dengan Slovin Formula yaitu

$$
n=\frac{548}{1+548(0,10)^{2}}=84,56
$$

Penelitian ini menggunakan tingkat kofidensial $10 \%$. Selanjutnya analisa dilakukan dengan Analisa Statistik Deskriptif dan Inferensial. Analisa Inferensial pada penelitian ini adalah untuk menjawab hipotesa berikut.

a. Belanja Modal berpengaruh terhadap Kerugan Daerah

b. Belanja Modal dengan Kelemahan SPI sebagai variabel moderasi berpengaruh terhadap Kerugian Keuangan Daerah;

c. Belanja Modal dengan Biaya Politik sebagai variabel moderasi berpengaruh terhadap Kerugian Keuangan Daerah; dan

d. Belanja Modal dengan Kelemahan SPI sebagai variabel moderasi lebih berpengaruh terhadap Kerugian Keuangan Daerah daripada biaya politik sebagai variabel moderasi

Untuk menjawab hipotesa tersebut maka analisis inferensia dilakukan dengan pembentukan model regresi linear berganda dengan variabel moderating dengan rincian sebagai berikut.

$$
\begin{aligned}
& \mathrm{Y}=\mathrm{a}+\mathrm{b} 1 \mathrm{x} 1 \ldots \ldots \ldots \\
& \mathrm{Y}=\mathrm{a}+\mathrm{b} 1 \mathrm{x} 1+\mathrm{b} \times 2+\mathrm{b} 3 \times 1 \times 2 \ldots \\
& \mathrm{Y}=\mathrm{a}+\mathrm{b} 1 \mathrm{x} 1+\mathrm{b} 3 \mathrm{x} 3 \mathrm{~b} 3 \times 1 \times 3 \ldots
\end{aligned}
$$

Dan analisa inferensia untuk menjawab hipotesis (d) adalah membandingkan hasil uji 
parsial (uji t) dari variabel pemoderasi Kelemahan SPI (X2) dan variabel pemodersi Biaya Politik (X3).

\section{HASIL DAN PEMBAHASAN}

Data dalam penelitian ini meliputi adalah data dari 99 satuan kerja atau lebih banyak dari sampel minimal dengan rincian sebagai berikut.

Tabel 1. Profil Responden

\begin{tabular}{|l|c|c|}
\hline \multicolumn{1}{|c|}{ Jenis Satker } & Frekuensi & Persentase \\
\hline Pemerintah Kabupaten & 75 & $75,76 \%$ \\
\hline Pemerintah Kota & 20 & $20,20 \%$ \\
\hline Pemerintah Provinsi & 4 & $4,04 \%$ \\
\hline \multicolumn{1}{|c|}{ Jumlah } & $\mathbf{9 9}$ & $\mathbf{1 0 0 \%}$ \\
\hline
\end{tabular}

Adapun keragaman data, pemusatan, dan ukuran data adalah sebagai berikut.

Tabel 2. Pemusatan, Ukuran, Keragaman Data

\begin{tabular}{|l|c|c|r|}
\hline \multicolumn{1}{|c|}{ Variabel } & Mean & S.Dev & \multicolumn{1}{c|}{ Kurtosis } \\
\hline Nilai Kerugian Negara (Y) & 0,2044 & 0,0674 & $-0,674$ \\
\hline Belanja Modal (X1) & 1,6263 & 0,8029 & 2,370 \\
\hline Kelemahan SPI (X2) & 2,1535 & 1,0519 & 0,785 \\
\hline Biaya Politik (X3) & 0,0054 & 0,0035 & 3,245 \\
\hline
\end{tabular}

Secara umum pemusatan dan letak data terpusat dapat dilihat dari nilai kurtosis tidak lebih dari 1,96 maupun tidak kurang dari -1,96. Rata-rata data tersebut terdistribusi normal untuk seluruh indikator kecuali indikator kualitas Belanja Modal (X1) dan Biaya Politik (X3). Untuk memastikan sebaran data terdistribusi normal akan dibahas lebih lanjut dalam uji asumsi klasik.

\section{Uji Asumsi Klasik}

Uji asumsi klasik bertujuan untuk memastikan bahwa model pengujian cukup handal dalam memberikan ketepatan estimasi, tidak bias, dan konsisten. Adapun hasil uji asumsi klasik menunjukkan hal berikut.

\begin{tabular}{|c|c|c|}
\hline Variabel & $\begin{array}{l}\text { Durbin } \\
\text { Watson }\end{array}$ & VIF \\
\hline Nilai Kerugian Negara (Y) & 2,062 & 1,029 \\
\hline Belanja Modal (X1) & 2,062 & 2,920 \\
\hline Kelemahan SPI (X2) & 2,062 & 2,871 \\
\hline Biaya Politik (X3) & 2,062 & 3,519 \\
\hline
\end{tabular}

Nilai Durbin Watson untuk pengujian variabel moderasi dengan tingkat keyakinan $10 \%$ dan jumlah sampel sebesar 99 sampel maka nilai tersebut masih dapat diterma. Sedangkan Variabel Inflation Factor masih berada dibawah 5 sehingga model persamaan regresi bebas terbebas dari autokorelasi dan multikolentenaritas. Sedangkan untuk uji normalitas dapat ditunjukkan pada gambar Scattter Plot dan Ppot berikut.
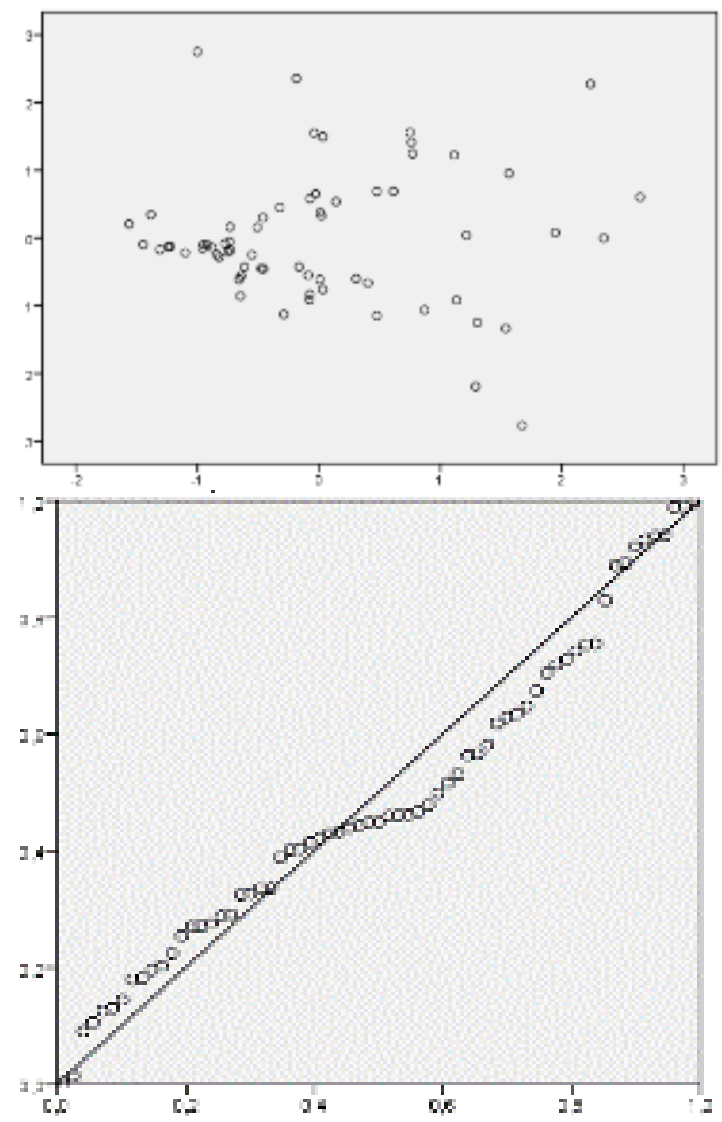

Gambar 1. (a) Scatterpot, (b) P-Plot

Gambar scatterplot menunjukkan bahwa data Sresidual dan Z-residual terlihat menyebar sehingga tidak terdapat permasalahan heterohedaktisitas. Selain itu, Gambar P-Plot menunjukkan data mengikuti garis P-Plot seehingga data tersebut terdistribusi normal.

\section{Analisa Inferensia}

Analisa Inferensia berupa regresi linear berganda dilakukan tiga kali dengan untuk mendapatkan perbandingan nilai R-Square dari variabel moderasi dengan rincian sebagai berikut.

a. Pengaruh Langsung antara Belanja Modal (X1) terhadap Kerugian Negara (Y);

b. Pengaruh Langsung antara Belanja Modal (X1) dimoderasi dengan Kelemahan SPI (X2) terhadap Kerugian Negara (Y);

c. Pengaruh Langsung antara Belanja Modal (X1) dimoderasi Biaya Politik (X3) terhadap Kerugian Negara (Y); dan

d. Membandingkan hasil nilai R-Square antara tiga persamaan regresi tersebut. 
Hasil analisa inferensia menunjukkan bahwa persamaan regresi dan nilai R-Square yang dibentuk sebagai berikut.

$$
\begin{aligned}
& Y=0,020+0,013 X 1 \\
& Y=-0,001+0,015 X 1+0,012 X 1 X 2 * \\
& Y=-0,001+0,009 X 1+0,009 X 1 X 3 *
\end{aligned}
$$

Tanda (*) menunjukkan variabel X2 dan X3 memiliki nilai uji t diatas 0,1 sehingga dikeluarkan dari persamaan. Adapun hasil perbandingan RSquare yang bisa dibentuk adalah sebagai berikut.

Tabel 2. Perbandingan Hasil R-Square

\begin{tabular}{|l|c|}
\hline \multicolumn{1}{|c|}{ Perbandingan Analisa Inferensia } & R-Square \\
\hline Pengaruh Langsung X1 terhadap Y & 0,122 \\
\hline Dimoderasi oleh Kelemahan SPI (X2) & 0,936 \\
\hline Dimoderasi oleh Biaya Politik (X2) & 0,667 \\
\hline
\end{tabular}

Hasil Analisa Inferensi menjawab hipotesis penelitian sebagai berikut.

a. Belanja Modal berpengaruh terhadap Kerugan Daerah ditunjukkan dengan persamaan (1) dengan nilai uji t sebesar 0,004 (signifikan) dan nilai R-Square sebesar 0,122.

b. Belanja Modal dengan Kelemahan SPI sebagai variabel moderasi berpengaruh terhadap Kerugian Keuangan Daerah dimana variabel Kelemahan SPI memperkuat hubungan tersebut dengan meningkatkan nilai R-Square dari 0,122 menjadi 0,936;

c. Belanja Modal dengan Biaya Politik sebagai variabel moderasi berpengaruh terhadap Kerugian Keuangan Daerah dimana Variabel Biaya Politik memperkuat hubungan tersebut dengan meningkatkan nilai R-Square dari 0,122 menjadi 0,667 ; dan

d. Kelemahan SPI lebih kuat memoderasi hubungan antaran Belanja Modal dengan Kerugian Keuangan Daerah dimana RSquarenya adalah sebesar 0,936 atau lebih besar daripada R-Square biaya Politik 0,667

\section{KESIMPULAN DAN SARAN}

Dari hasil penelitian tersebut dapat disimpulkan bahwa secara bawaan Kerugian Keuangan Daerah bisa terjadi dalam Belanja Modal (R-Square 0,122). Namun, apabila terdapat kelemahan SPI dalam pengelolaan Belanja Modal di Daerah berpotensi kuat memperbesar Kerugian Keuangan Daerah. Selain itu, Biaya Politik juga berpotensi memperbesar Kerugian Negara. Namun demikian, kelemahan SPI lebih kuat mempengaruhi daripada Biaya Politik.

Hasil penelitian ini menunjukkan bahwa Pemerintah Daerah perlu memperkuat SPI pengelolaan Belanja Modal. Sedangkan untuk Pemeriksa/Auditor, identifikasi kelemahan SPI untuk menerapkan Risk Based Audit sangat direkomendasikan untuk mendeteksi adanya Kerugian Keuangan Daerah. Penelitian ini juga diharapkan berguna Aparat Penegak Hukum (APH) seperti KPK, Kepolisian, dan Kejaksaan dalam membuktikan unsur mens rea dalam kasus Kerugian Keuangan Daerah.

\section{DAFTAR PUSTAKA (Memuat hanya pustaka yang dirujuk saja)}

Abhan, (2015-2018) Indeks Kerawanan Pemilu, 2015-2018

Ade Irawan, Abdullah Dahlan, Donal Fariz, Almas Ghalia Putri. Panduan Pemantauan Korupsi Pemilu, Indonesia Corruption Watch 2014. hlm. 42-43

Amarru Muftie Holish, Rohmat, Iqbal Syarifudin, (2008), "Money Politic dalam Praktik Demokrasi Indonesia, SNH UNNES, Vol 4 Nomor 2 Tahun 2018

Arens, A.A., Elder, R.J., Beasley, M.S. 2011. Auditing dan Pelayanan Verifikasi: Pendekatan Terpadu, edisi kesembilan, Jakarta: Indeks.

Arens, Alvin A., Beasley , Mark S., and Elder, Randal J. 2012. "Auditing and Assurance Services", Pearson Education, 2016

Boyle, Edmund J., Steven M. Cooper, dan Marshall A. Geiger. 2004. An empirical analysis of intern control weaknesses under SAS No.78: An Examination of State Audit Reports. Accounting Faculty Publications. Paper 16

Clawson, James. (2008). Systems Theory and Organizational Analysis. Management Educator: Courses, Cases \& Teaching eJournal

Cressey, D. R. (1953). "Other People's Money”. Montclair, NJ: Patterson Smith, pp.1-300

Dowding, Keith., Dunleavy, Patrick., King, Desmond., Margetts, Helen., "Political Studies", Sage Journals, Vol 43, Issue 2, 1995

Fitri, Diana. 2014. "Pengaruh Belanja Pegawai Dan Belanja Modal Terhadap Flypaper Effect”, Universitas Negeri Padang, 2014

Fitriyah, MA. 2013. "Fenomena Politik Uang dalam Pilkada", Universitas Diponegoro, Semarang 2013

Greenberg, J.; Pyszczynski, T.; Solomon, S.; Rosenblatt, A.; Veeder, M.; Kirkland, S.; Lyon, D. (1990). "Evidence for terror management II: The effects of mortality salience on reactions to those who threaten or bolster the cultural worldview". Journal of 
Personality and Social Psychology. 58 (2): 308-318

Heider, F. (1958). The Psychology of Interpersonal Relations. New York: Wiley

Ikhtisar Hasil Pemeriksaan Semesteran BPK RI Tahun 2016-2017

KAREN S. COOK AND ERIC RICE • Department of Sociology, Stanford University, Stanford, California 94305, Handbook of Social Psychology, edited by John Delamater. Kluwer Academic/Plenum Publishers, New York, 2003

Keputusan MA No. 2223 K/Pid.Sus/2012 Tahun 2012

Keputusan Pengadilan Negeri Nomor : 139/Pid.Sus/TPK/2015/PN.Jkt.Pst Tahun 2016

Keputusan Pengadilan Tinggi DKI Jakarta Nomor 17/PID/TPK/2013/PT.DKI tangggal 27 Maret 2013

Kompas " KPK Temukan Pola "Fee" 10 Persen dalam Kasus Korupsi Proyek Pemerintah", https://nasional.kompas.com/read/2017/09/17/ 16380411/kpk-temukan-pola-fee-10-persendalam-kasus-korupsi-proyek-pemerintah. (diakses tanggal 30 November 2018)

Ludwig Von Bertalanffy, "General System Theory" , 1968

Mackevičius, Jonas \& Giriūnas, Lukas. (2013). TRANSFORMATIONAL RESEARCH OF THE FRAUD TRIANGLE. Ekonomika. 92. 150-163. 10.15388/Ekon.2013.0.2336.

Martini, K,. Dwiandra, AANB., (2015), PENGARUH KINERJA KEUANGAN DAERAH PADA ALOKASI BELANJA MODAL KABUPATEN DAN KOTA DI PROVINSI BALI, Jurnal Udayana Vol 10 No. 2 Februari 2016

Michels, Robert. Political Parties - A Sociological Study of the Oligarchical Tendencies of Modern Democracy, Jarrold \& Sons. London, 1916

Millichamp, A.H, Taylor. 2012. "Auditing", Cengage Learning EMEA, 2002

Milyo, Jeff, 2015, Campaign Spending and Electoral Competition: Towards More Policy Relevant Research, University of Missoury, A Journal of Applied Research in Contemporary Politics Volume 11, Issue No. 3 (October 2013), p. 437-45

Republika "JK Sebut Anggaran Belanja Barang Kerap Jadi Sasaran Korupsi", https://www.republika.co.id/berita/ekonomi/m akro/17/11/30/p087ia415-jk-sebut-anggaranbelanja-barang-kerap-jadi-sasaran-korupsi. (diakses tanggal 30 November 2018)
Ruppel, Warren. 2014. "Wiley GAAP for Government", Penerbit: John Wiley and Sons; 2014

Saerang, Paul David Elia., Dama, Saskia Tria., Elim Inggriani. 2016. "Pengaruh Pendapatan Asli Daerah Dan Dana Alokasi Umum Terhadap Belanja Modal di Kota Bitung 2003-2013", Jurnal Berkala Ilmiah Efisiensi, Volume 16 Nomor 3 Tahun 2016

Sendhikasari, Dharmaningtias,. Hantoro, Novianto Murti (2016), "Antisipasi Potensi Kerawanan Pilkada", Puslit DPR : 2016

Shao, Stephanie. 2016. "Best Practices for Internal Controls to Prevent Occupational Fraud in Small Businesses", PDXScholar, Portland

Widyastuti, Anita. 2016. "Hubungan Belanja Pemerintah Daerah dan Probabilitas Terjadinya Korupsi Pada Pemerintah Daerah di Indonesia", Universitas Gadjah Mada, Yogyakarta, 2016

Wolfe, D., \& Hermanson, D. R. (2004). "The fraud diamond: Considering four elements of fraud." The CPA Journal, Vol 74, 38-42

Yamin, Ridha, dan Sutaryo. 2017. "Faktor Penentu Jumlah Temuan Kelemahan Sistem Pengendalian Intern pada Pemerintah Daerah di Indonesia”, IBS, Jakarta 2017

Yuntho, Emerson. 2014. Penerapan Unsur Merugikan Keuangan Negara dalam Delik Tindak Pidana Korupsi”, ICW, 2014

Yusuf, Muhamat, Aryani, Anni Y. 2015, "Karakteristik Kepala Daerah, Afiliasi Partai Politik dan Indikasi Korupsi Belanja Modal". Jurnal Integritas Volume 1 Nomor 1 November 2015. 